\title{
Mapping of the $\mathrm{X}$ linked form of hyper IgM syndrome (HIGM1)
} M Padayachee, R J Levinsky, C Kinnon, A Finn, C McKeown, C Feighery,
L D Notarangelo, R W Hendriks, A P Read, S Malcolm
Molecular Immunology Unit, Institute of Child Health, 30 Guilford Street, London WC1N 1EH.

R J Levinsky

C Kinnon

A Finn

Department of Clinical Genetics, Birmingham Maternity Hospital, Birmingham B15 2TG.

C McKeown

Department of Immunology, St James's Hospital, PO Box 580, James's Street, Dublin 8. $C$ Feighery

Department of Paediatrics, University of Brescia, 25123 Brescia, Italy.

L D Notarangelo

Department of Immunohaematology, University Hospital, Rijnsburgerweg 10, 2333 AA Leiden, The Netherlands. R W Hendriks

Department of Medical Genetics, St Mary's Hospital, Hathersage Road, Manchester M13 OJH. A P Read

Correspondence to Dr Malcolm.

Received 30 September 1992 Revised version accepted 20 November 1992.

\begin{abstract}
Molecular Genetics Unit, Institute of Child Health, 30 Guilford Street, London WC1N 1EH. M Padayachee S Malcolm

Abstract

$X$ linked immunodeficiency with hyperimmunoglobulinaemia M (HIGM1), which is characterised by agammaglobulinaemia together with excess IgM production reflecting an impairment of the immunoglobulin heavy chain class switch of B lymphocytes, has been mapped to Xq26. We report multipoint linkage data in six families with HIGM1 which show that the most likely position for the gene is close to HPRT with a maximum lod score of $\mathbf{4} \cdot 89$. The finding of recombinations between HIGM1 and both HPRT and DXS42 implies that HIGM1 is not allelic to $X$ linked lymphoproliferative disease. These data will be useful in genetic counselling in families and will also be useful in testing candidate genes. ( 7 Med Genet 1993;30:202-5)
\end{abstract}

A number of inherited immunodeficiencies mapping to the $\mathrm{X}$ chromosome have been described and their chromosomal locations reported. ${ }^{1}$ Immunodeficiency with hyper IgM is characterised by raised levels of IgM, normal or raised levels of $\mathrm{IgD}$, and very low levels of IgG, IgA, and IgE in the serum and secretions. ${ }^{2}$ Although clinically indistinguishable, several genetic defects may give rise to the same syndrome since it can be X linked, autosomal recessive, or autosomal dominant. All forms are exceptionally rare but the $\mathrm{X}$ linked form predominates. ${ }^{3}$

HIGM1 was shown not to be allelic to Brutons agammaglobulinaemia $(A G M X 1){ }^{4}$ Using nine $\mathrm{X}$ chromosome specific DNA probes recognising RFLPs, Mensink et al assigned the HIGM1 gene to Xq24-27 in a single pedigree. This pedigree, typed for additional markers, has been incorporated into this study. Hendriks et $a l^{6}$ extended the linkage study on the same family and confirmed linkage to DXS42 (Xq24-q25) with a maximum lod score of $2 \cdot 29$. Three families with HIGM1 were analysed, and showed linkage to HPRT using a VNTR (AGAT) tetranucleotide repeat. ${ }^{78}$

Here we extend the number of families and include other probes flanking HPRT using both conventional RFLPs and short tandem repeat polymorphisms.

\section{Materials and methods}

FAMILIES STUDIED

Six families were available for study, most of which have been reported previously. Family
Cou was first described in 1962 (fig 1$)^{9}$ and is discussed by McKusick (30823). ${ }^{10}$ Subjects IV.4, IV.5, and IV.8 have died since the family was first reported and subjects IV.6, IV.9, and IV.10 have been born since 1962. Surviving family members II.3, II.4, III.3, III.4, III.8, IV.1, IV.6, and IV.10 were typed. An EBV transformed cell line from IV.10 was generously provided by Dr C Roifman. Preliminary linkage data on four families EsX, HB, MM, $\mathrm{WG}^{58}$ has been reported. The same subjects were typed in this study. The sixth family, $\mathrm{Tu}$, is presented in fig $1 .^{11}$

OLIGONUCLEOTIDE PRIMERS

Primers identifying STRs at the loci $H P R T,{ }^{12}$ $D X S 425,{ }^{13}$ and $D X S 102^{13}$ were synthesised on an $\mathrm{ABI}$ 3801A synthesiser. The sequences used were:

(1) HPRT (AGAT)n, forward 5' < TCT CTA TTT CCA TCT CTG TCT CC $>3^{\prime}$, reverse $5^{\prime}<$ TCA CCC CTG TCT ATG GTC TCG $>3$ ', product size: $159 \mathrm{bp}$.

(2) $D X S 425$ (XL 90A3) (CA)n, forward $5^{\prime}<$ TCT AGA GTC GAT CAC GTG AG $>3^{\prime}$, reverse $5^{\prime}<$ TTA GTC ATG ATT CCC CAG AG $>3$ ', product size: $101 \mathrm{bp}$.

(3) $D X S 102(\mathrm{C} \times 38 \cdot 1)$ (CA)n, forward 5'< GTA GTC TCA GTC GAC ATG CTT TGA > 3', reverse 5'< GCT GAG AAA GTA GAT CCT AAG TGT TC $>3$, product size: $157 \mathrm{bp}$.

PROBES

The following probes were used for the linkage analysis: $43-15$ (from locus DXS42) 14 $^{14}$ and 36B2 (from locus DXS10). ${ }^{15}$

SOUTHERN BLOT ANALYSIS

DNA was extracted from the nuclei of peripheral leucocytes by guanidinium hydrochloride extraction. ${ }^{16}$ Twenty micrograms of DNA was digested for at least four hours with the appropriate enzyme and the fragments separated on a $0.8 \%$ gel by electrophoresis. After denaturation of the gel with $0.4 \mathrm{~mol} / 1$ $\mathrm{NaOH}, 1.5 \mathrm{~mol} / \mathrm{l} \mathrm{NaCl}$, the DNA was blotted directly onto Hybond $\mathrm{N}+$ (Amersham International) and fixed by rinsing with $0.4 \mathrm{~mol} / \mathrm{l}$ $\mathrm{NaOH}$ followed by two washes with $2 \times$ SSC.

DNA probes were radiolabelled to a specific activity of $10^{9}$ to $10^{10} \mathrm{cpm} / \mu \mathrm{g}$ with ${ }^{32} \mathrm{P}$-dCTP by random hexanucleotide primer extension. Prehybridisation and hybridisation were carried out in $10 \times$ Denhardt's solution, $4 \times \mathrm{SSC}, 50 \mu \mathrm{g} / \mathrm{ml}$ sonicated salmon sperm 
II

III

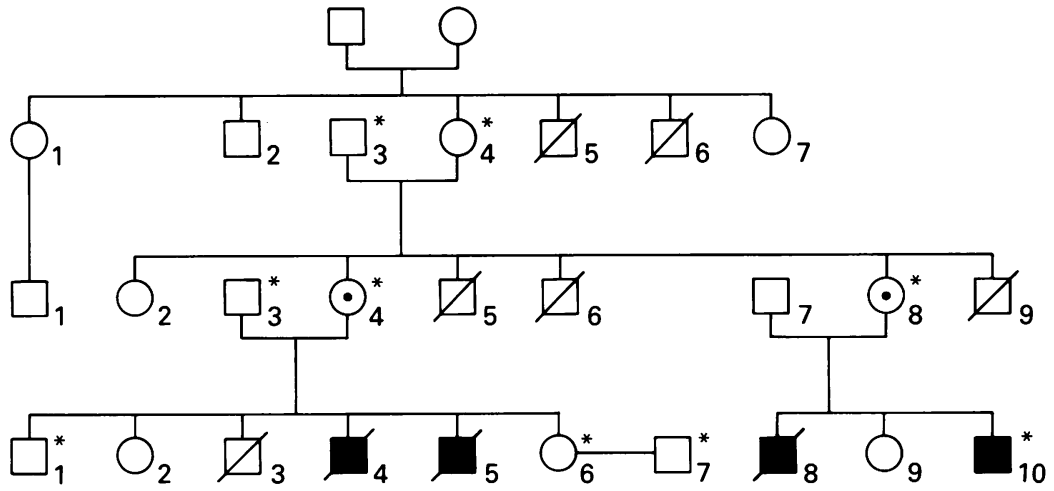

IV

Family Cou

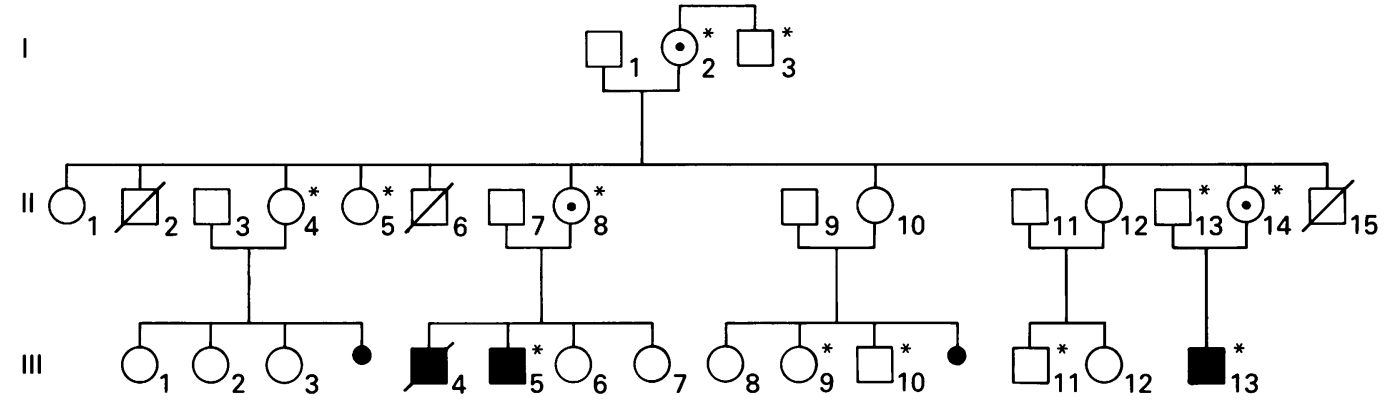

*Subjects typed

Family Tu

Figure 1 Pedigrees of families Cou and Tu.

DNA, and $0 \cdot 1 \%$ SDS overnight. Filters were washed for $3 \times 20$ minutes in $3 \times$ SSC, $0 \cdot 1 \%$ SDS at room temperature followed by further higher stringency washes at $65^{\circ}$. Autoradiography was performed using $x$ ray film (Kodak XAR-5) with two intensifying screens at $-70^{\circ}$ for 72 hours.

\section{PCR ANALYSIS}

Reactions were carried out in a $25 \mu$ l volume using $100 \mathrm{ng}$ of genomic DNA, $12.5 \mathrm{pmol}$ of each primer, $200 \mathrm{nmol}$ dATP, dTTP, dGTP, $20 \mathrm{nmol}$ dCTP, $0 \cdot 1 \mu \mathrm{l}{ }^{32} \mathrm{P}$-dCTP, in reaction buffer $\left(1.5 \mathrm{mmol} / 1 \mathrm{MgCl}_{2}, 50 \mathrm{mmol} / 1 \mathrm{KCl}\right.$, $10 \mathrm{mmol} / 1 \mathrm{Tris}-\mathrm{HCl}, \mathrm{pH} 9 \cdot 0,0 \cdot 10 \%$ gelatin, $0 \cdot 1 \%$ Triton $\mathrm{X}$ ), and $10^{-5} \mathrm{~mol} / 1$ tetramethyl ammonium chloride. Reactions were overlaid with mineral oil, denatured at $94^{\circ} \mathrm{C}$ for 10 minutes before cooling to $60^{\circ} \mathrm{C}$, and 1.5 to 2 units of $T a q$ polymerase (Promega) were added. Twenty-five cycles of $72^{\circ} \mathrm{C}$ (one minute), $94^{\circ} \mathrm{C}$ (one minute), and $60^{\circ} \mathrm{C}$ (30 seconds) were carried out on a Techne PHC-2 machine.

For analysis $1 \mu \mathrm{l}$ PCR product was diluted five-fold with TE, and stop solution (95\% formamide, $20 \mathrm{mmol} / 1 \mathrm{EDTA}, 0.05 \%$ bromophenol blue, $0.01 \%$ xylene cyanol) (USB), denatured for two minutes at $90^{\circ} \mathrm{C}$ and $2 \mu \mathrm{l}$ loaded on a $6 \% \quad 19: 1$ acrylamide:bisacrylamide, denaturing polyacrylamide (Acugel) gel and electrophoresed at 55 watts for two hours on BRL sequencing apparatus. The gel was then dried on to $3 \mathrm{M}$ Whatman paper. Autoradiography was performed using $x$ ray film (Kodak XAR-5) at $-70^{\circ} \mathrm{C}$ overnight.
LINKAGE ANALYSIS

Two point lod scores were analysed using the LIPED programme (version $4 \cdot 8$ ). A gene frequency of 0.0001 was used. Complete penetrance of HIGM1 was assumed. The allele frequencies that were used are given below. The frequencies for the microsatellites were measured from 90 Caucasian chromosomes. The RFLP frequencies have been published. ${ }^{17}$

(1) HPRT 0.167: 0.396: 0.292: 0.104: 0.041.

(2) DXS425 0.144: 0.333: 0.274: 0.144: 0.105.

(3) DXS102 0.800:0.050: 0.050: 0.050: 0.050.

(4) $D X S 420 \cdot 810: 0 \cdot 190$.

(5) $D X S 100 \cdot 330: 0 \cdot 670$

Multipoint linkage data were analysed using the LINKMAP program (version 5.04) run via the MRC HGMP Resource Centre. Map distances were set according to published data.

\section{Results}

Fig 1 shows pedigrees Cou and $\mathrm{Tu}$. The other pedigrees are fully described in Hendriks et al ${ }^{6}$ and Padayachee et al. ${ }^{8}$

Two point lod scores with the loci $D X S 42$ and $D X S 10$ and the VNTR polymorphisms $H P R T, D X S 425$, and $D X S 102$ are presented in table $1 . Z \max$ and $\theta \max$ for each locus are presented in table 2 .

A multipoint map from $D X S 425$ to $D X S 102$ is presented in fig 2 . The order of the markers used is DXS425-DXS42-HPRTDXS10-DXS102 based on genetic map evidence for DXS425-DXS42-HPRT $T^{1819}$ and physical mapping in a YAC contig for HPRTDXS10-DXS102.20

The region around HPRT has been com- 
Table 1 Two point lod scores.

\begin{tabular}{lcccccccc}
\hline & \multicolumn{7}{c}{ Recombination fraction $\theta$} \\
\cline { 2 - 9 } Marker & 0.5 & 0.4 & 0.3 & 0.2 & 0.1 & 0.05 & 0.001 & 0 \\
\hline DXS425 & 0 & 1.37 & 2.202 & 2.976 & 3.041 & 2.284 & -5.506 & -294.927 \\
DXS42 & 0 & 0.598 & 1.201 & 1.693 & 1.713 & 1.929 & 0.453 & -97.435 \\
HPRT & 0 & 0.874 & 1.935 & 3.239 & 4.419 & 4.891 & 3.877 & -94.304 \\
DXS10 & 0 & 0.216 & 0.601 & 1.020 & 1.419 & 1.606 & 1.780 & 1.783 \\
DXS102 & 0 & 0.337 & 0.623 & 0.868 & 1.065 & 1.267 & 1.142 & 1.142 \\
\hline
\end{tabular}

Table 2 Zmax and $\theta \max$ for each locus.

\begin{tabular}{lll}
\hline Marker & $Z \max$ & $\theta \max$ \\
\hline DXS425 & 3.157 & $0 \cdot 14$ \\
DXS42 & 1.983 & 0.08 \\
HPRT & 4.952 & 0.03 \\
DXS10 & 1.783 & 0 \\
DXS102 & 1.142 & 0 \\
\hline
\end{tabular}

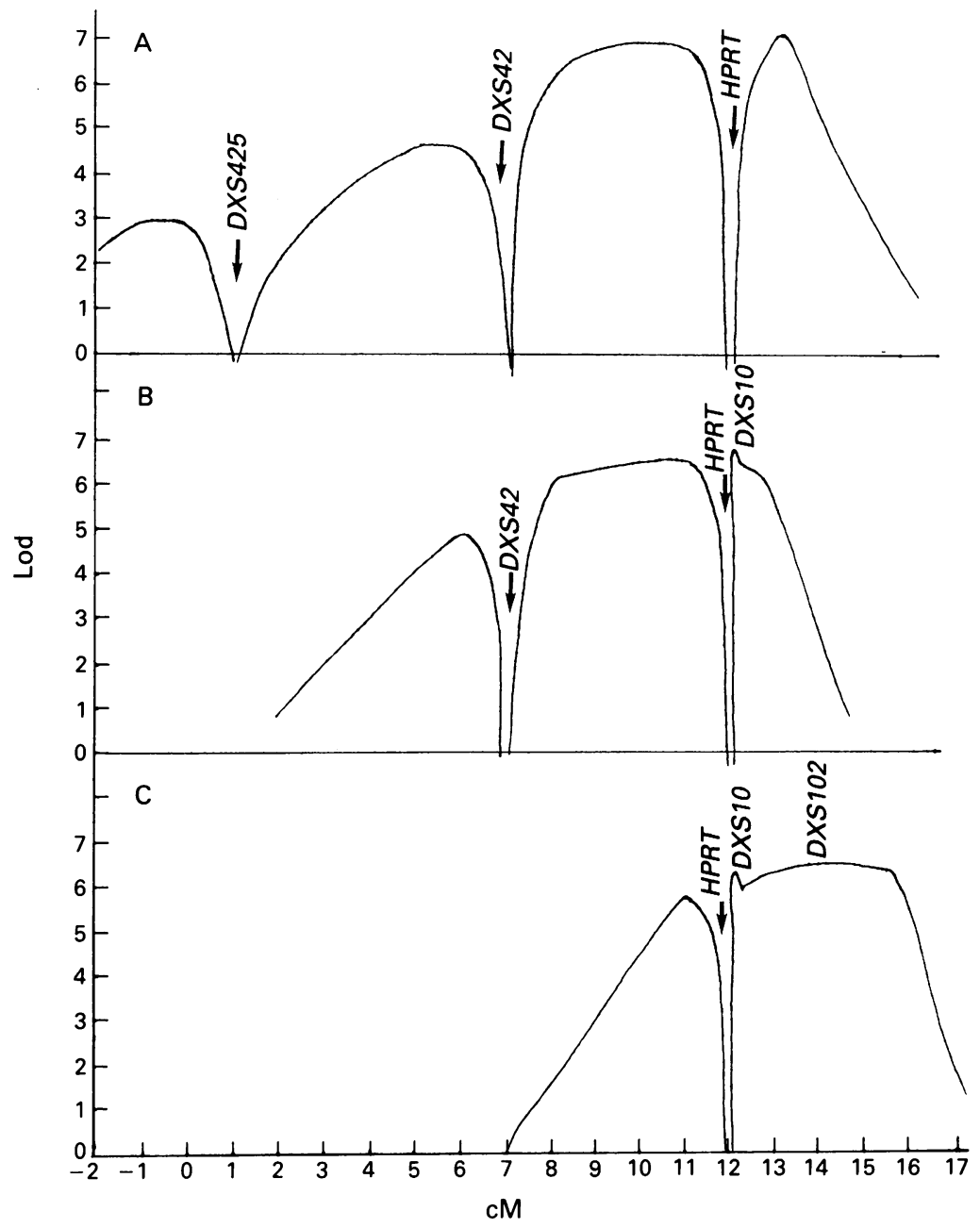

Figure 2 Multipoint linkage analysis of HIGM1. The disease plus three markers were analysed in each case. ( $A$ ) DXS425-DXS42-HPRT, (B) DXS42HPRT-DXS10, (C) HPRT-DXS10-DXS102.

pletely isolated in a set of YACs covering $8 \mathrm{Mb}$ of DNA. ${ }^{20} H P R T$ is at the centromeric end of this YAC contig and $D X S 10$ is $1 \mathrm{Mb}$ distal. $D X S 102$ is $5.7 \mathrm{Mb}$ distal within $200 \mathrm{~kb}$ of factor 9. The genetic distances from $H P R T$ to the proximal markers $D X S 425(11 \mathrm{cM})$ and $D X S 42(5 \mathrm{cM})$ were taken from published work. ${ }^{1819}$ The genetic distance between $H P R T$ and $F 9$ has been measured ${ }^{18}$ as $2.5 \mathrm{cM}$. This is lower than would be expected from the physi- cal distance between the genes of $5.9 \mathrm{Mb}$ and indicates that this is a region of low recombination. Based on the known physical distances between HPRT-DXS10-DXS102, and F9 the genetic distances were set at $H P R T-0 \cdot 2 \mathrm{cM}$ DXS10-2.5 cM-DXS102.

Recombinations between DXS425 and the disease locus were found in families Cou, $M M$, and WG. In family Cou recombinations between DXS425 and HIGM1 were found in the meioses between subject II.4 and one of her daughters III. 4 or III. 8 both of whom are obligate carriers, and between III.4 and her unaffected son IV.1. In the first case $H P R T$ also recombines with the disease, but in the second there is a recombination between $D X S 425$ and HPRT with HPRT segregating with the disease. This is the only recombinant between HPRT and HIGM1 and the two point lod score is 4.89 at a recombination fraction of 0.05 . No definite recombinations were found with $D X S 10$ or DXS102 making the exact position of HIGM1 unclear.

Five of the six families were tested with probe 43-15 (DXS42). Family HB showed a recombination between DXS42 and HIGM1. The same meiosis did not recombine with HPRT confirming a localisation of the disease gene distal to $D X S 42$. The most distal marker tested, $D X S 102$, showed no definite recombinations.

\section{Discussion}

Our multipoint linkage analysis in six HIGM1 pedigrees show that the locus for HIGM1 is closely linked to the HPRT locus on Xq26.1. We found a maximum lod score of $4 \cdot 89$, which makes the HPRT polymorphism, together with its high heterozygosity value, useful in genetic counselling. This is important, as the finding of random $\mathrm{X}$ chromosome inactivation patterns in $\mathrm{B}$ and $\mathrm{T}$ cells ${ }^{1}$ preclude carrier detection by $\mathrm{X}$ chromosome inactivation analyses.

The localisation of HIGM1 makes testing of candidate genes possible. Unlike $\mathrm{X}$ linked agammaglobulinaemia where there is usually a complete absence of circulating B cells, in this disease IgM and IgD expressing B cells are normal or increased while those expressing other isotypes are decreased. However, the finding of random $X$ inactivation patterns in $B$ cells expressing IgM, IgG, and IgA as well as the $T$ cell series, in at least some families, makes it unlikely that the defect is of B cell origin. ${ }^{621}$

The clinical features of $\mathrm{X}$ linked agammaglobulinaemia and hyper IgM syndrome differ. In both diseases, not surprisingly, bacterial infections predominate and severe mouth 
ulcers and neutropenia may occur as presenting features. ${ }^{3}$ However, despite no laboratory evidence of any $T$ cell mediated immunodeficiency in either disease, it is only in patients with the $\mathrm{X}$ linked hyper IgM syndrome that opportunistic infections such as Pneumocystis carinii, cryptosporidium, and aspergillosis, so characteristic of cell mediated immunodeficiency, occur (Morgan and Levinsky, personal communication).

The genotype of HIGMl could not be distinguished from XLP as both loci were mapped to Xq25-26 and in both diseases the B and $T$ cell populations manifest random $X$ chromosome inactivation. Our finding of a recombination between $H I G M 1$ and HPRT indicates that HIGM1 is located distal to HPRT. This implies that HIGM1 is not allelic to $X L P$ as linkage data and the finding of $\mathrm{Xq} 25$ deletions in $X L P$ indicate that $X L P$ is proximal to the HPRT locus. ${ }^{22}$

Since isotype switching is thought to be under $\mathrm{T}$ cell control, a defect in this mechanism would be more likely and this is supported by the description of a Sezary cell derived $T$ cell clone being able to induce $\mathrm{B}$ cells from $\mathrm{X}$ linked hyper IgM patients to produce IgG in culture. ${ }^{23}$ The factor involved has not yet been described but the finding of several new cytokines and their receptor ligands acting on $B$ cells either to induce differentiation or isotype switching make these possible candidate genes. ${ }^{24} 25$

MP holds a Medical Research Council HGMP studentship. We are grateful to the Child Health Research Appeal Trust for financial support.

1 Hendriks RW, Schuurman RKB. Genetics of human X linked immunodeficiency diseases. Clin Exp Immunol 1991;85:182-92.

2 Rosen FS, Kevy SV, Merler E, et al. Recurrent bacterial infections and dysgammaglobulinemia: deficiency of $7 \mathrm{~s}$ gammaglobulin in the presence of elevated $19 \mathrm{~s}$ gammagammaglobulin in the presence of

3 Notarangelo LD, Duse M, Ugazio AG. Immunodeficiency with hyper-IgM (HIM). Immunodeficiency Rev 1992; 3:101-22.

4 Malcolm S, De Saint Basile G, Arveiler B, et al. Close linkage of random DNA fragments from Xq21.3-22 to X linked aggamagloblinaemia (XLA). Hum Genet 1987;77:172-4

5 Mensink EJBM, Thompson A, Sandkuijl LA, et al. X linked immunodeficiency with hyper IgM appears to be linked to DXS42 RFLP. Hum Genet 1987;76:96-9.

6 Hendriks RW, Sandkuyl LA, Kraakman MEM, et al. RFLP linkage and $X$ chromosome inactivation analysis in $X$ linked immunodeficiency. In: Chapel HM, Levinsky RJ, Webster ADB, eds. Progress in immune deficiency III London: Royal Society of Medicine, 1991:266-71.

7 Edwards AL, Civitello A, Hammond HA, et al. DNA typing and genetic mapping with trimeric and tetrameric typing and genetic mapping with trimeric and tetram

8 Padayachee M, Feighery C, Finn A, et al. Mapping of the X linked form of hyper IgM syndrome (HIGM1) to Xq26 linked form of hyper lgM syndrome (HIGM1) to X

9 Jamieson WM, Kerr MR. A family with several cases of hypo-gammaglobulinaemia Arch Dis Child 1962;37:330-

10 McKusick VA. Mendelian inheritance in man. 9th ed. Baltimore: Johns Hopkins University Press, 1990:1654

1 Notarangelo LD, Parolini O, Albertini A, et al. Analysis of $\mathrm{X}$ chromosome inactivation in $\mathrm{X}$ linked immunodeficiency with hyper-IgM (HIGM1): evidence for involvement of different hematopoietic cell lineages. Hum Genet 1991;88:130-4.

12 Hearne CM, Todd JA. Tetranucleotide repeat polymorphism at the HPRT locus. Nucleic Acids Res 1991;19:5450.

13 Luty JA, Guo Z, Willard HF, et al. Five polymorphic microsatellite VNTRs on the human X chromosome. $A m$ m Hum Genet 1990;46:776-83.

14 Aldridge J, Kunkel L, Burns G, et al. A strategy to reveal high frequency RFLPs along the human X chromosome. Am $\mathcal{F}$ Hum Genet 1984,36:546-64.

15 Reilly DS, Lewis RA, Nussbaum RL. Genetic and physica mapping of Xq24-q26 markers flanking the Lowe oculocerebrorenal syndrome. Genomics 1990;8:62-70.

16 Jeanpierre M. A rapid purification of DNA from blood Nucleic Acids Res 1987;15:9611.

17 Kidd KK, Bowcock AM, Schmidtke J, et al. Report of the committee and catalogs of cloned and mapped genes and DNA polymorphisms. Cytogenet Cell Genet 1989;51:622947.

18 Huang THM, Hejtmancik JF, Edwards A, et al. Linkage of the gene for an X-linked mental retardation disorder to a hypervariable (AGAT)n repeat motif within the human hypervariable (AGA he repeat motif within the human hypoxanthine phosphoribosyltransferase
(Xq26). Am ₹ Hum Genet 1991;49:1312-9.

19 Huang THM, Cottingham RW, Ledbetter DH, et al. Genetic mapping of four dinucleotide repeat loci, DXS453, DXS458, DXS454 and DXS424, on the X chromosome using multiplex polymerase chain reaction. Genomics 1992;13:375-80

20 Little RD, Pilia G, Johnson S, et al. Yeast artificial chromosomes spanning 8 megabases and $10-15 \mathrm{cM}$ of human cytogenetic band Xq26. Proc Natl Acad Sci USA 1992;89:177-81.

21 Hendriks RW, Kraakman MEM, Craig I, et al. Evidence that in $\mathrm{X}$ linked immunodeficiency with hyper-immunoglobulinaemia the intrinsic immunoglobulin heavy chain class switch mecl

22 Skare J, Grieson $\mathrm{H}$, Wyandt $\mathrm{H}$, et al. Genetics of the $\mathrm{X}$ linked lymphoproliferative syndrome. Am $\mathcal{f}$ Hum Genet 1989;45:A161.

23 Mayer L, Kwan SP, Thompson C, et al. Evidence for a defect in "switch" $T$ cells in patients with immunodeficiency and hyperimmunoglobulinaemia $M$. N Engl f Med 1986;314:409-13.

24 Gascan H, Gauchat JF, Aversa G, et al. Anti-CD40 monoclonal antibodies or CD4 ${ }^{+} \mathrm{T}$ cell clones and IL-4 induce IgG4 and IgE switching in purified B cells via different signalling pathways. F Immunol 1991;147:8-13.

25 Armitage RJ, Fanslow WC, Strockbine L, et al. Molecular and biological characterization of a murine ligand for CD40. Nature 1992;357:80-4. 
For The Blind to support gene mapping of autosomal dominant nystagmus.

1 Hemmes GC. Over hereditairen nystagmus. Wageningen: H Veerman \& Zonen, 1924.

2 Forssman B, Ringner B. Prevalence and inheritance of congenital nystagmus in a Swedish population. Ann Hum Genet 1971;35:139-47.

3 Forssman B. Hereditary studies of congenital nystagmus in a Swedish population. Ann Hum Genet 1971;35:119-39.

4 Forsythe WI. Congenital hereditary vertical nystagmus. $f$ Neurol Neurosurg Psychiatry 1955;18:196-8.

5 Von Noorden GK, Preziosi TJ. Eye movement recordings in neurological disorders. Arch Ophthalmol 1966;76:16271 .

6 Dell'Osso LF, Flynn JT, Daroff RB. Hereditary congenital nystagmus: an intrafamilial study. Arch Ophthalmol 1974;92:366-74

7 Spooner SN, Bateman JB, Yee RD. Congenital nystagmus in identical twins: discordant features. $\mathcal{F}$ Pediatr Ophthalmol Strabism 1986;23:115-9.

8 Creel D, O'Donnell FF, Witkop CJ. Visual system anomalies in human ocular albinos. Science 1978;201:931-3.

9 McKusick VA. Mendelian inheritance in man. 9 th ed. Baltimore: Johns Hopkins University Press, 1990.

10 Fisher T. Congenital nystagmus in father and child. $B M F$ 1902:ii:694.

11 Hawthorne CO. Nystagmus in three generations. BMF 1903;i:425.

12 Fattowich G. Sul nistagmo congenito familiare. $G$ Psichiat Neuropatol 1936;64:393.

13 Allen $M$. Three pedigrees of eye defects: primary hereditary nystagmus. Case study with genealogy. $f$ Hered 1942;33:454-6.

14 Gresty M, Page N, Barrett $H$. The differential diagnosis of congenital nystagmus. I Neurol Neurosurg Psychiatry $1984 ; 47: 936-42$.

15 Hammerstein W, Gebauer HJ. Familiarer nystagmus und hypoplastic der makula bei reziprober, balanzierter translocation 5/16. Fortschr Ophthalmol 1989;86:718-21.

\section{Corrections}

In the paper by Richards et al on 'Detailed genetic mapping of the von Hippel-Lindau disease tumour suppressor gene' $(\mathcal{F} M e d$ Genet 1993;30:104-7), an important collaborator, Dr Per Enblad, was inadvertently omitted from the authorship. The correct authorship is as follows. Richards FM, Maher ER, Latif F*, Phipps ME, Tory K*, Lush M, Crossey PA, Oostra B $\dagger$, Enblad P $\ddagger$, Gustavson KH $\ddagger$, Green J§, Turner G\|,
Yates JRW, Linehan Mף, Affara NA, Lerman $M^{*}$, Zbar B*, Ferguson-Smith MA.

Cambridge University Department of Pathology, Cambridge, UK; *Laboratory of Immunobiology, National Cancer Institute, Frederick Cancer Research Facility, Frederick, USA; †Erasmus University, Rotterdam, The Netherlands; $\ddagger$ University of Uppsala, Sweden; $\S$ Division of Community Medicine, Memorial University of Newfoundland, Canada; || Yorkshire Regional Genetics Service and ICRF Genetic Epidemiology Laboratory, Leeds, UK; ๆSurgery Branch, National Cancer Institute, USA.

In the paper by Padayachee et al on 'Mapping of the X linked form of hyper IgM syndrome (HIGM1)' ( $($ Med Genet 1992;30:202-5), the primer sequence for DXS102 ${ }^{13}$ under the heading OLIGONUCLEOTIDE PRIMERS was referenced Luty et al. This is incorrect and should be:

Gedeon AK, Holmon K, et al. Characterization of new pcr based markers for mapping and diagnosis: AC dinucleotide repeat markers at the DXS237 (GMGX9) and DXS102 (cX38.1) loci. Am $\mathcal{F}$ Med Genet 1992;43:255-60. 